New Zealand journal of industrial relations, 1988, 13, 179-189

\title{
The struggle for power and control in the new corporations: the first year of industrial relations in the state-owned enterprises
}

\section{Pat Walsh*}

The objective of this paper is to identify and discuss the principal industrial relations issues that have emerged in the first year of operation of several of the new state-owned enterprises (SOES). The paper does not cover all the SOEs, nor does it pretend to analyse all the industrial relations issues of the first year of their operation. It is based on research and interviews conducted with unions and management in 6 of the SOEs - Electricorp, Forestrycorp, Airwayscorp, NZ Post, Telecom and Postbank. Its focus is not on a detailed analysis of the agreements negotiated in the new corporations, but rather upon the nature of the relationships that have emerged there. The SOEs were established as a policy decision to shift state trading enterprises away from the public service orientation inherent in their status as departments of state to a new emphasis upon commercial criteria. The issue I wish to address in this paper is the extent to which the character of industrial relations in the SOEs has reflected this shift in orientation.

Issues of power and control have been the chief considerations in the industrial relations of the SOEs so far. This is not surprising. The setting up of the SOEs broke with organisational structures and accompanying industrial relations and personnel arrangements that had developed over at least 75 years. Trade unions and management had adjusted structurally and operationally to those arrangements and their relations with each other had been moulded within them. Their relations were of a continuing nature in which present outcomes were shaped by past practices. Union and management organisation, membership and management attitudes and actions, political and economic considerations, statutory prescription and tribunal interpretation had formed a configuration from which came a particular balance of industrial forces. This varied across time, sector and issues. Corporatisation altered that configuration. It changed the nature of its components and it weighted them differently. This was not a neutral intervention. By replacing past practices with radically new ones, the Government disrupted the existing balance of forces and opened the door to a struggle for power and control in the new corporations. This paper is an initial effort to chart the first year of that struggle. 


\section{The background to corporatisation}

One would normally expect the early period of new types of organisations like the SOEs to be marked by a struggle for control between unions and management. This expectation is enhanced when one considers the policy objectives of corporatisation and the circumstances in which the SOEs were established. Corporatisation is an early and striking example of the Government's wider programme of state restructuring which has . become a key aspect of its economic policy and whose pace has quickened remarkably since 1985. It is not an exaggeration to say that the role of the state has become the central political question in New Zealand. In the first half of 1988 alone, the State Sector Act, the Gibbs and Picot reports, the Royal Commission on Social Policy and major reviews of several Government departments have all spoken to different dimensions of this. In this context, corporatisation was important because it established a particular way of thinking about the appropriate role of the state. Since then, the principles which underpinned this have bid fair to become the new orthodoxy in social and economic policy.

At the heart of the corporatisation model of the state is a set of arguments about the allocation, deployment and assessment of resources, including human resources, that have significant relevance for industrial relations. The economic justification for corporatisation centered on the claimed inefficiencies of state trading enterprises as they were constituted prior to 1987. The full arguments in support of this position are well-known (Treasury, 1984; Gregory, 1987). Both the diagnosis and the recommended solution implied major industrial relations change. This stemmed immediately from the statutory requirement that the SOEs be run as successful businesses in which commercial criteria were to predominate in all decisions. Managerial autonomy and accountability were elevated to the forefront and managerial performance was to be measured against the yardstick of maximum efficiency in the allocation of resources. Behind this lay the argument that efficiency had been impeded in the past by restrictive practices, either imposed by unions or agreed to by weak management, and by a burdensome set of personnel and wage-fixing rules which inhibited managerial performance. To this end the personnel and industrial relations arrangements of the state sector were no longer legislatively mandated for the new corporations. Thus, corporatisation had as one important policy agenda the reassertion of managerial control in the workplace.

The circumstances in which the corporatisation policy was developed also made it more likely that control would be a central issue in the SOEs. There were three elements to this. One was the dominant role by Treasury in promoting corporatisation over the opposition of the State Services Commission (Gregory, 1987, p.113). The second was the exclusion of the state unions from influential involvement in the process. The third was the appointment to the Establishment Boards of private sector employers, many of them members of the Business Roundtable. Together, these three factors clarified the character of the coalition pushing for corporatisation and the links between it and wider economic policy concerns. In particular, it clarified corporatisation's connection with ideas of labour market deregulation in both the private and state sectors. An important aspect of that agenda is a denial of the legitimacy of trade unions and a determination to restore the primacy of management in the workplace. Promotion of that agenda necessarily poses the issue of control.

\section{Management strategies}

The analysis in this paper is premised on the view that managerial rather than union initiatives provide the key to industrial relations in the first year of the SOEs. This does not derive from a belief in union weakness but from an assessment of the structural and political circumstances surrounding the establishment of the corporations. They are new 
organisations set up to realise specific policy objectives to do with managerial efficiency and performance. New organisational and management structures were introduced, significant changes were made in operational practices within the corporations, and in many cases new personnel were appointed. Established industrial relations procedures were discarded in favour of a new regime based on markedly different rules and procedures. Moreover, unlike the State Sector Act, the SOE Act did not carry over any conditions of employment; all had to be negotiated afresh under radically different circumstances. Similarly, political factors handed the advantage to management. The members of the corporation boards and senior management, especially chief executives, were appointed in circumstances which raised expectations with regard to managerial initiatives. They were a new breed of private sector managers brought in to remedy the inefficiencies of the past and to make the SOEs viable, even profitable commercial enterprises. Their reputations and that of the Government were thought to be at least partly dependent on their . implementation of innovative and commercially successful policies. The impetus for change came from the management side of the fence; it is therefore to be expected that management initiatives will establish the framework for industrial relations in the first year of operation.

Nonetheless, despite the broadly similar forces at work, there has been considerable variation in the industrial relations strategies adopted by management in the six SOEs in this study. At a general level, and mindful of the risk of over-simplification, it appears that they fall into 3 categories. All 6 have sought to assert managerial control. The variation stems from the degree to which the control strategies they have chosen permit the development of good working relations with the trade unions which represent their employees. Forestrycorp and Electricorp have chosen strategies which have made it exceedingly difficult to develop satisfactory relations with their unions. Strategies followed by Postbank and Airways have had mixed implications for relations with unions, both jeopardising and encouraging them. In contrast, NZ Post and Telecom appear to have given higher priority than the other four to the development of good union relations. This categorisation is not immutable. On particular issues, the corporations may not fall into this hierarchy, whilst over time, a corporation may shift strategies and become more or less antagonistic towards trade unions. At present, there is some evidence suggesting that Telecom is adopting a more adversarial stance towards the Post Office Union than was the case over the first 12 months.

Thus, it is apparent that accounting for the industrial relations differences among the new corporations may be as important and as interesting a task as pointing to the broad patterns established in the first year of their operation. The 6 were established at the same time, for the same reasons, and as part of the same overall policy. And yet, divergent industrial relations practices became visible within the first year. Why? At this stage, it is possible only to begin to sketch what a full answer to this question might look like. Much of the answer is not accessible and has to do with internal policy decisions at the highest level of the organisations. Time will permit more considered and informed judgements than those attempted here, but the contemporary relevance is such that the issue can not be put to one side.

Electricorp and Forestrycorp appear to have had the clearest understanding of industrial relations as an integral component of their corporate strategy. In each case, a policy decision was taken to establish an industrial relations regime designed to maximise efficiency and thus profitability. This may be related to to the particular attitudes towards the role of trade unions held by Board members and senior management. In Electricorp's case, the new industrial relations approach became plainly visible after it was restructured. It may be expected that the current restructuring in Telecom may produce similar outcomes, especially if a decision is made to follow the Electricorp line of independent competitive business units.

Past relations with unions have been important. NZ Post, Telecom and Postbank have profited from the historically good relations between the Post Office and the Post Office 
Union. However, present relations are at least partially dependent on how past relations are interpreted. Postbank appeared to view the joint consultation which occurred in the Post Office as spilling over into joint management and was determined not to start down that path. It is notable that its relations with the POU have been more adversarial than those of the other two. As one example, it alone of the 3 rejected a union suggestion of joint working parties prior to negotiations to clarify positions and assist in reaching a settlement.

Union organisation and strength have materially influenced management strategies. In the Post Office, industrial strength lay with workers now with either Telecom or NZ Post, but not with bank employees. Similarly, Forestrycorp have sought to take advantage of the relative industrial weakness of their employees. Conversely, as in Electricorp, industrial strength can also provide incentives for a control-oriented management to adopt . a rigorously uncompromising stance in an effort to reverse the balance of forces. The degree of competition faced by an SOE has had an impact on its industrial relations policies. Forestrycorp faces direct and visible competition from other forestry companies and it is clear that this has strongly influenced its employee strategy. Postbank faces direct competitors, unlike NZ Post and Telecom, although the latter is alert to the implications of de-regulation and the possibility of future competition.

\section{Negotiations in the SOEs}

Most SOEs have now completed two rounds of negotiations. The first usually resulted in a transitional determination promulgated under the State Services Conditions of Employment Act which took effect from April 1 1987. For the most part, the transitional determinations carried over existing conditions of employment. The main departures from the status quo were in the areas of union coverage and personnel procedures, both of which will be discussed below. Forestrycorp stood out in those negotiations. It adopted a characteristically control-oriented approach from the start. Forestrycorp was unusual among the SOEs in that it dealt with 3 unions. It concluded an agreement with the Timberworkers union based on longstanding relativity with the agreements in the other main forestry companies. It was unable to settle a transitional determination with the NZ Workers union or the PSA. Forestrycorp believed that a number of state conditions of employment, including union coverage, were incompatible with its need to compete with its private sector rivals. Forestrycorp unilaterally issued a transitional determination to cover Workers union members on March 31 1987, and offered individual contracts of employment to PSA members. It took until May 1988 to conclude an agreement with the Workers union; the PSA agreement is still outstanding.

Other SOEs also had difficulty in settling their first actual agreement following their transitional determination. These agreements were negotiated under the terms of the Labour Relations Act. Of the SOEs in this study, Airways and Electricorp had the most problems. In neither case did wages constitute the difficulty. Indeed, the emphasis upon issues related to power and control meant that wages and salaries were not contentious issues in the SOEs. The major difficulty in the wages area was the refusal of Airways to backdate its wage increase, a position upheld in mediation. The need to recruit and retain good staff predominated in wage negotiations, and all the SOEs followed the trend set in the private sector. There had been some discussion prior to the wage round that an SOE might become a trend-setter, but this did not eventuate. The only departure from the going rate was the 8.2 percent in Electricorp, which partly followed the higher electricians' settlement in the private sector, but much more importantly was a trade-off for the PSA's acceptance of 7 separate agreements to cover Electricorp's 7 new business units. I shall return to the Electricorp settlement below. There is increasing use throughout the SOEs of performance-based salary scales such as Hay or Price Waterhouse. In future union advocates may find themselves negotiating over locations on such a scale. These may pose 
a potential problem for unions in that many union members see them as objective and support their use, whereas unions prefer a collective-based bargaining system.

There has been little substantial change in formally prescribed national conditions of employment. The chief impetus for change has come from management reluctance to include particular local or administrative conditions in the national agreements. This has been an important issue in the current negotiations to consolidate the 7 Electricorp documents. One area where there has been change is equal employment opportunity, and that is examined separately below. Other than Forestrycorp, Airways was the only corporation to mount an attack on specific employment conditions. Their campaign to alter the basis of shift rosters resulted in the corporation gaining the right to implement new procedures if it chooses to do so, a result consistent with the new stress on managerial discretion. In this context, day-to-day conditions of employment have undergone change, as management has sought to establish unquestioned control at the workplace itself.

\section{Union coverage}

Struggles over power and control in New Zealand industrial relations have not usually involved the issue of union coverage. One reason is that management has had little structural opportunity to involve itself in the matter. Indeed, it has historically been a matter resolved not by the parties themselves but by others. In the state sector, union coverage has been settled politically, by means of Ministerial recognition, while in the private sector the legislatively-prescribed registration process has settled the issue administratively. Such disputes as there have been over union coverage have tended to be inter-union demarcation disputes rather than union/management conflicts. The nature of the industrial relations system, which had at its centre the resolution of disputes by representative organisations of unions and employers, also discouraged employers from questioning the system of union coverage, as did the pragmatic acceptance by most employers of the necessary role played by unions.

The setting up of the SOEs offered an opportunity to break with that pattern. Unlike most management in taking over an existing enterprise or establishing a new one, the management of the SOEs did not inherit an established system of union coverage. It was an unsettled issue, both in terms of which unions, if any, would have coverage, and the level at which coverage would apply.

Policy objectives converged with structural opportunity. Many of those appointed to senior management and the Establishment Boards shared the view that the historically poor performance of state trading enterprises was attributable to weak management and strong unions. They were determined to reverse this. Added to this was the articulation of a new managerial antagonism to the very principle of trade unionism, which found expression among some of the SOE appointees. This represented a significant departure from traditional managerial ideology in New Zealand, and can be traced partly to the increasingly important role in industrial relations played by chief executives and the loss of predominance by the more pragmatic industrial relations professionals. This itself derives from a variety of causes related to the restructuring of the economy.

There was some SOE resistance to the principle of union coverage and delayed Ministerial recognition of the PSA in Electricorp, the first to settle the union coverage principle. In practice, the focus shifted to the level of coverage. All SOEs tried to minimise the scope of union coverage, thus enhancing managerial control. In general, most began from a position of wanting to confine coverage to positions with salaries below the coverage level in the Clerical Workers' award. This was entirely unacceptable to the unions as it would have deprived them of a significant proportion of their membership. In the case of Postbank, for instance, the loss would have been about 30 percent. The issue was settled by specifying a set of senior managerial positions exempt 
from union coverage. The coverage loss has not been great. It is less than 3 percent in the three corporations covered by the Post Office Union; while for those covered by the PSA, the loss appears to have varied between 5 and 15 percent. The strongest resistance to retention of high levels of union coverage was in Forestrycorp, where PSA coverage remains very low, and in Electricorp. All the SOEs place great emphasis upon direct communication with their employees over the heads of the unions, in an effort to shift workers' loyalty away from the union to the corporation.

The resolution of the union coverage issue should not be regarded as final. In many of the SOEs, management is unhappy at the outcome so far, and views the current position as negotiable in the future renewal of agreements. The main management thrust so far has been on personnel matters, to which we shall turn in a moment. To some degree, management success there, which was considerable, was traded off against union coverage. But there can be no doubt that in some SOEs, unions will soon be faced with balancing particular conditions of employment against union coverage levels. The union coverage status quo is better than in the private sector. Management in the SOEs place great store by equivalence with the private sector, and this, combined with the ideological and policy reasons mentioned above should ensure that union coverage remains a central industrial relations issue in the corporations.

\section{Managerial prerogatives}

There has been a consistent and uniform drive by SOE management to restore managerial discretion in all areas. The personnel procedures in the State Services Act 1962 became a key target in all SOEs. Existing statutory provisions with regard to merit appointments, appeals, promotions, transfers, classification, grading and termination were eliminated and replaced by provisions giving management vastly increased discretion. The statutory requirement to be a good employer in section 4 of the SOE Act did not prevent this. Sweeping away the state services personnel procedures (now removed there too) was seen as essential both to managerial authority and to being a commercially profitable enterprise. There appears to have been no significant union resistance to this. These are difficult issues on which to mobilise members, especially given the general strategic weakness of the unions. The personnel provisions of the State Services Act were an integral part of the structure of a non-political career service. The removal of the SOEs from this context robbed unions of much of the justification for their retention.

The personnel provisions of the State Services Act should be seen as equal opportunity measures, as was made plain in the debate over the State Sector Act in 1988. Their elimination has significant implications for the redress of employment inequality. Although the SOEs' statutory requirement to be a good employer includes the implementation of an equal opportunity programme, the corporations have not so far been notable for including progressive EEO policies in their industrial agreements. The overall picture is complex, but some issues are clear. Most of the SOEs have reduced maternity leave conditions to the provisions of the Parental Leave and Employment Protection Act 1987 which are inferior in important respects to those in the public service; there is little if any commitment to support for setting up child-care centres for SOE staff; sick leave and domestic leave conditions are worse in some cases; and, there is little evidence of carrying over either the Maori and Pacific Islander recruitment programmes or the equality management programmes. Other EEO provisions such as permanent part-time work, flexible working hours and bereavement leave (including tangihangi leave) are often worded in such a way as to give management much greater discretion in their implementation. Equal employment opportunity measures are seen as limiting the capacity of management to turn the SOEs into commercial profit centres. They too have been a casualty of the managerial drive for the reassertion of control. 
Once again, it is difficult for unions to mobilise their members on these issues and it is evident that existing EEO provisions are likely to be targeted by the SOEs in the next round of negotiations. Already, influential commentators are preparing the ideological ground for such an attack (Jennings and Cameron, 1987, p.151). The policy implications are that under the present balance of industrial forces, equal opportunity measures require both statutory protection in the form of specific entitlements and enforcement mechanisms. Both are lacking in the SOEs. It remains to be seen whether the situation will develop differently in the state services under the State Sector Act, where the enforcement role of the State Services Commission is considerable.

Consultation was an important area where the issue of managerial prerogative was posed sharply. The changes in this area appear to be most visible in Electricorp and in the three corporations that have emerged from the Post Office. As government departments, these organisations had a centralised, highly consultative and cooperative decision-making process in which the unions enjoyed considerable influence. In the SOEs, management has tried to diminish union influence over decisions by moving decisively away from a genuinely consultative approach, although, as we shall see, there is some variation in the degree to which this has happened.

In Electricorp, this rejection of consultation was expressed in a bitter conflict over job losses. In September 1987, Electricorp had completed its restructuring process which had fallen behind schedule. It decided that it needed to shed 800 positions, which itself breached its earlier agreement with the PSA that there would be no substantial job losses. On its own admission, Electricorp was determined not to enter negotiations with the PSA on the issue, and only grudgingly was it prepared to permit its local managers to engage in a very restricted form of consultation with the PSA. This led directly to notice of industrial action. Electricorp then secured an ex parte injunction against the PSA, which curtailed the planned action. The injunction was based on Electricorp's claim that the PSA's advice on its proposals to minimise the impact of the action in fact constituted a breach of the notice of action. In turn, the PSA obtained its own injunction against Electricorp binding it to the terms of their agreement. Neither injunction went to a full hearing, and the issue was disposed of by an administrative agreement.

The significance of the dispute was two-fold. At one level, it concerned Electricorp's decentralisation of authority to local managers and the PSA's reaction to that. We shall return to this below. At another level, its significance lay in the importance Electricorp attached to not negotiating with the PSA over job losses and in being seen not to negotiate. Electricorp regarded the dispute as an opportunity to establish that its management policies would differ substantially from those of its predecessor, the New Zealand Electricity Department (NZED). This was made plain by the manner in which it took the injunction against the proposed industrial action. In the past, industrial action by electricity staff had normally been directed against the Government (as in the derecognition disputes of 1979 and 1983) or the State Services Commision rather than against NZED itself. This reflected the centralisation of industrial relations under the previous regime and the limited role played by the department. In those circumstances the PSA and NZED had cooperated to minimise the impact of the action. This had involved staff staying on the job and being paid while limiting production but not distribution and thus not affecting the consumer. In this case, Electricorp, as the target of the action, decided it would not cooperate as its predecessor had done, and that it would exploit the offer of cooperation to secure the injunction. Moreover, it decided to refuse to pay workers during the limited action that did take place, while gambling that they would not walk off the job.

Whatever ethical reservations individual Electricorp managers may have had about these strategies - and there is some suggestion that not all were entirely happy with them they were seen as crucial to distingush Electricorp management polices from those of its predecessor. Electricorp management believes that its conduct of the dispute showed its own managers, its Board, its employees and the PSA that it was determined to control the operation of the corporation. It was important for Electricorp that this be done early and 
with conviction. In that sense, the dispute served important managerial purposes and clarified Electricorp's expectations about power relations in the corporation. The other side of the dispute is the impact it had on employee relations and the manner in which it embittered those directly involved from the electricity group and from the staff of the PSA. This may have significant long-term consequences, but these were not important policy concerns for Electricorp at the time.

The shift away from consultative management has been apparent in Postbank, Telecom and NZ Post also. The Post Office operated with an elaborate network of joint union/management consultative arrangements. Indeed to outsiders, the Post Office appeared to constitute a remarkable example of power-sharing. One obvious spin-off of this was the industrial harmony that prevailed there. However, under corporatisation, these arrangements were viewed as a major contributor to the claimed inefficiencies of the Post Office and as a reason for corporatisation. They soon became a natural target for the new management and have in fact been eliminated in all 3 corporations. However, as noted earlier, the 3 vary considerably in the extent to which they continue the practice of cooperation depending on their interpretation of the meaning of the joint consultation procedures of the past.

\section{Decentralisation of managerial authority}

A key development in all the SOEs has been the decentralisation of managerial authority. (There is some suggestion that Airways Corporation is in the process of recentralising authority, but if so this process is only in the very early stages.) Before corporatisation, decision-making, including industrial relations and personnel matters, was highly centralised. Decentralisation poses a challenge to both union and management structures. For management, the challenge in many SOEs has been to develop its own industrial relations management. In the past, the now-corporatised government departments were able to downgrade the importance of industrial and personnel skills, since the SSC made the major, and even the minor decisions in these areas. This is no longer the case. The need to bring in new management, including some from the private sector unaware of past practices and, if made aware, unsympathetic to those that varied from the private sector, has hastened the process of change, especially in terms of establishing a private sector-oriented model of management control. It is significant that this process of change has been least dramatic in the 3 corporations drawn from the Post Office, which had a well-developed industrial relations management structure.

The other challenge posed for management by the decentralisation of authority was to change the attitudes of regional and local management who were accustomed to exercising little autonomy and to referring issues back to the centre. This clashed with the emphasis upon decentralised, accountable, performance-oriented management. In the Post Office, management had also been able to take refuge in the processes of joint consultation and to avoid making decisions in cases where the union's view had not been established. This has raised the question of how successfully and responsibly local management are exercising their new authority. Inevitably, the picture is mixed and the evidence so far is anecdotal only. Some union officials suggest that there has been a marked increase in dismissals and other disciplinary measures, but the evidence is not conclusive. Other union officials have remarked, with some sympathy, upon the great pressures placed upon local management under the new policies and the stress generated for them by the relentless emphasis upon performance. On the other hand, SOE management appeared aware of the turmoil that corporatisation had involved for middle management at the local level and concerned to minimise its impact.

For unions, the challenge posed by the decentralisation of managerial authority has been significant. Their structures had developed historically to meet corresponding management structures and the location of management decisions. At the same time these 
structures shaped and were shaped by the fact that union/management bargaining generated nationally uniform outcomes. Accordingly, state unions had developed quite differently from their private sector counterparts. Above all they were national in structure and centralised in operation. The sudden management shift away from this and perhaps also from national conditions of employment demanded an organisational response of the unions.

The decentralisation process has gone furthest in Electricorp, which has restructured itself into 7 autonomous business units. Electricorp regarded the securing of 7 separate agreements to cover the business units as vital to its restructuring process. To secure the 7 agreements, Electricorp was willing to carry over existing conditions of employment from the transitional determination, to offer an above-average wage settlement and to take industrial action from the PSA without seeking any restraining injunctions. One reason for the lack of injunctions was that in response to the earlier injunction the PSA has now become scrupulously legalistic in its notices of industrial action. The other was that in this case, unlike the dispute over job losses, a mutually satisfactory settlement was one of Electricorp's objectives.

For the PSA and the electricity group in particular, devolution and fragmentation appeared to threaten the basis of their power which had always operated at a national level and in terms of the electricity group as a whole. In practice, the impact would depend upon the strategic resources of workers in the different units, and it is difficult to predict this with confidence, although it does appear that in some units resources would be limited. Clearly, the existence of 7 agreements raises the possibility of different conditions of employment in the 7 units. In all SOEs, as in the state services since the State Sector Act, there is theoretical potential for departure from national conditions of employment within the same organisation.

Unions have begun the organisational changes needed to adapt to these structural changes in management decision-making. The Post Office Union, which was previously highly centralised in its operations, has had to shift staff resources from its central office out to the regions to cope with the new decision-making patterns. The PSA has always placed more emphasis upon its regional structure, at least in terms of its full-time officials, whilst giving rather less of a role to local and regional elected officials, reflected in the anachronism of a (soon to be abolished) entirely Wellington-based Executive Committee. The PSA is undergoing a major organisational review at present, and corporatisation has been an additional factor, although a significant one, to be considered in that process. For all unions caught up in corporatisation, the decentralisation of managerial authority has reinforced the importance of developing an informed and trained delegate structure, effective communication structures and internally democratic procedures which ensure responsiveness to members' needs. The new management structures put an end to any notions that the national union office is best placed to know about important developments and to articulate the policies most appropriate to deal with them. The possibility of varying conditions and policies being followed in different regions and organisational units means that traditional assumptions about national uniformity have to be abandoned.

The trade union response to the new environment introduced by corporatisation has been subject to frequent criticism. Much of this criticism comes from opposing vested interests and can be appropriately discouliid. Other arguments warrant more serious consideration. These centre on whether the unions responded to corporatisation in ways that best protected the interests of their members. Some members were eager to break out of what they saw as the confines of the state system and were confident they would do well out of the new system. These members saw the unions as opposing new opportunities for them. Others with more modest ambitions sometimes claimed that the unions were more concerned with the problems of those without jobs at the expense of getting the best conditions for those still in jobs. Conversely, others whose jobs were lost 
or threatened did not see the unions as providing very practical assistance to them or as effectively mobilising resources to protect their jobs.

It is not possible easily to evaluate the validity of these arguments. For every anecdote of union inadequacy, another of union success can be offered. However, there are structural and contextual reasons why unions would have difficulty adapting to corporatisation. As the examples above show, corporatisation divides union members and generates conflicting demands on unions. Corporatisation does this to management too. But it is easier to change management structures and practices than to do the same in a union. It is not a simple contrast of democratic versus hierarchical models. Rather, it has to do with the contrasting character of unions and companies as organisations, especially in their authority relations, incentive structures and decision-making processes.

Management personnel have career ambitions that are fostered by achieving the policy objectives prescribed for them by senior management who retain powerful sanctions for breaches. In unions, objectives are not so much prescribed as evolved from what may be a lengthy process in which the opportunities for delay, diversion, sabotage or plain nondecision are endless. Members, or more accurately activists, are in a much less subordinate position than their counterparts in companies. They may resist official objectives once decided and agitate for change. There is no readily available means of disciplining them for this since resistance is tolerated in principle if not welcomed in practice, and there are few sanctions available to senior union personnel with which to compel activist compliance since neither their jobs nor their future careers depend on union personnel. Thus in a process of radical change such as corporatisation, management is strategically better placed than unions to set objectives quickly and compel their achievement. This is especially so when, as with corporatisation, it is a management-initiated process of change from which unions were largely excluded and which cut across membership solidarity.

\section{Conclusions}

Corporatisation proceeded at a remarkable pace. It took only 16 months from the first policy statement in December 1985 to the operation of the new corporations in April 1987. Restructuring by the corporations since then has maintained the relentless impetus for change. The impact upon individuals and communities has been dramatic. At an organisational level, unions and the SOEs have had to shape a new relationship under vastly altered circumstances from those that prevailed before. This process is very much in its infancy. The crucial issue in this period has been the struggle for power and control. The SOEs have enjoyed structural and contextual advantages and have made significant advances. The capacity of the unions to reverse those advances depends on the balance of economic and political forces, not least of which is privatisation. There is little in the broad context that gives reason to expect a reversal of present trends in the industrial relations of the SOEs. Thus any significant recovery by unions is likely to depend on organisational factors, especially industrial strength, cohesion, solidarity and leadership. These qualities are not evenly distributed and they are not easily brought to bear on all issues. Therefore, there is likely to be an uneven pattern of development in the mediumterm future; the days of uniformity appear to be finished.

\section{References}

Gregory, R (1986) The reorganisation of the public sector: the quest for efficiency. In J Boston \& M Holland (Eds) The fourth Labour government: radical politics in New Zealand Auckland, Oxford University Press. 
Jennings, S \& Cameron, R(1987) State-owned enterprise reform in New Zealand. In A Bollard \& R Buckle (Eds) Economic liberalisation in New Zealand Wellington, Allen \& Unwin.

Treasury (1984) Economic management Wellington, Government Printer. 


\section{BRITISH JOURNAL OF INDUSTRIAL RELATIONS}

\section{Edited by Ben Roberts, Ray Richardson, and David Metcalf}

"A source of invaluable information and research for anyone involved in industrial or personnel relations."

LEN PEACH, PRESIDENT, INSTITUTE FOR PERSONNEL MANAGEMENT

The British Journal of Industrial Relations publishes a wide range of articles covering both the theory and practice of industrial relations. The primary focus is on developments in Britain and other advanced industrial countries, especially the USA, the EEC, Japan and the Commonwealth, but issues in developing countries are also analysed.

\section{Recent articles include:}

Employee share option schemes; why workers are attracted to them PHILIP DEWE, STEPHEN DUNN and RAY RICHARDSON

Factors affecting the development of employee financial participation in contemporary Britain: evidence from a national survey

DR M. J.F.POOLE

Explaining the strike proneness of British companies in Ireland AIDAN KELLY and TERESA BRANNICK

Taxation and strikes: the post-war experience in Three Countries GREG HUNDLEY

British Journal of Industrial Relations is published in March, July, November Subscription Rates Volume 26, 1988

Individuals: $£ 14.30$ (UK) $£ 17.80$ (overseas) US\$29.50 (N. America)

Institutions: $£ 30.00$ (UK) $£ 37.50$ (overseas) US\$58.75 (N. America)

$\square$ Please enter my subscription to British Journal of Industrial Relations/send me a sample copy

$\square$ I enclose cheque/money order made payable to Basil Blackwell

$\square$ Please charge my Access/American Express/Barclaycard/Diners Club/ Mastercharge/Visa account number:

\section{Card expiry date}

$\square$ For payments via the National Giro Bank, the Basil Blackwell account number is 2366053

Address

Please return this form together with your payment if applicable to:

Basil Blackwell • Journals Dept., 108 Cowley Road, Oxford OX4 1JF or Journals Dept., Box 1320, Murray Hill Station, NY 10156, USA. 